\title{
Paenibacillus jilunlii sp. nov., a nitrogen-fixing species isolated from the rhizosphere of Begonia semperflorens
}

Correspondence

San-Feng Chen

chensf@cau.edu.cn

\author{
Hao-Jie Jin, ${ }^{1}$ Yu-Guang Zhou, ${ }^{2}$ Hong-Can Liu ${ }^{2}$ and San-Feng Chen ${ }^{1}$ \\ ${ }^{1}$ State Key Laboratory for Agrobiotechnology, Department of Microbiology and Immunology, \\ College of Biological Sciences, China Agricultural University, Beijing 100193, PR China \\ ${ }^{2}$ China General Microbiological Culture Collection Center, Institute of Microbiology, Chinese \\ Academy of Sciences Datun Road, Chaoyang District, Beijing 100101, PR China
}

As early as 1908, nitrogen-fixing strains of Bacillus polymyxa were found to be associated with plants (Von Bredemann, 1908). In 1991, Ash et al. (1991) proposed the splitting of the genus Bacillus into three distinct groups. The genus Paenibacillus was then erected (Ash et al., 1993, 1994) on the basis of phylogenetic and 16S rRNA gene sequence analyses of group 3 bacilli. Continued transfers of species of the genus Bacillus to the genus Paenibacillus and further descriptions of novel members of the genus Paenibacillus have increased the number of species in the genus Paenibacillus considerably (Shida et al., 1997; Saha et al., 2005). At the time of writing, the genus contained more than 100 species (http://www.bacterio.cict.fr/ $\mathrm{p} /$ paenibacillus.html) and the type strains of 16 species

Abbreviation: SEM, scanning electron microscopy.

The GenBank/EMBL/DDBJ accession numbers for the 16S rRNA and nifH gene sequences of Paenibacillus jilunlii sp. nov. Be $17^{\top}$ are G0.985393 and G0985392, respectively.

Supplementary figures are available with the online version of this paper. have been reported to exhibit nitrogenase activities, including Paenibacillus polymyxa, P. macerans, P. peoriae, $P$. graminis, $P$. odorifer, $P$. brasilensis, $P$. azotofixans, $P$. borealis, $P$. wynnii, $P$. massiliensis, $P$. sabinae, $P$. zanthoxyli, $P$. donghaensis, $P$. forsythiae, $P$. riograndensis and $P$. sonchi (Beneduzi et al., 2010; Coelho et al., 2009; Hong et al., 2009).

Members of this genus are widely distributed in nature and have diverse physiological characteristics. Some species consistently show a high capacity to fix atmospheric nitrogen in vitro (Elo et al., 2001; Berge et al., 2002; Ma et al., 2007; Ma \& Chen, 2008). In this study, we describe the isolation and classification of a novel nitrogen-fixing species within the genus Paenibacillus based on phenotypic properties, 16S rRNA gene sequences, DNA G + C content, DNA-DNA relatedness, chemotaxonomic properties and nifH gene sequences.

The bacterial strain studied was isolated from rhizosphere soil of Begonia semperflorens plants planted in Beijing 
Botanical Garden, Beijing, PR China. The soil was collected near the plant roots from a depth of $30 \mathrm{~cm}$. Samples were transported to the laboratory as soon as possible. A $1 \mathrm{~g}$ sample of soil was placed in $9 \mathrm{ml}$ sterile water and stirred for $30 \mathrm{~min}$. Aliquots of $100 \mu \mathrm{l}$ from the aqueous portion of the mixture were heated at $80{ }^{\circ} \mathrm{C}$ for $15 \mathrm{~min}$ and then spread on nitrogen-free medium (Ma et al., 2007) in triplicate and incubated at $30{ }^{\circ} \mathrm{C}$. One colony that grew very well on nitrogen-free medium and exhibited nitrogenase activity was selected and incubated at $30{ }^{\circ} \mathrm{C}$ for 3 days for further study.

To determine cell morphology, the novel isolate, strain Be $17^{\mathrm{T}}$, was grown on endospore-forming medium $(0.07 \%$ yeast extract, $0.1 \%$ tryptone, $0.1 \%$ glucose, $0.02 \%$ $\left(\mathrm{NH}_{4}\right)_{2} \mathrm{SO}_{4}, 0.02 \% \mathrm{MgSO}_{4} .7 \mathrm{H}_{2} \mathrm{O}, 0.1 \% \mathrm{~K}_{2} \mathrm{HPO}_{4}(\mathrm{w} / \mathrm{v})$, $\mathrm{pH}$ 7.0) for $14 \mathrm{~h}$. Cell morphology was examined by scanning electron microscopy (SEM). Cell motility was determined by observing the growth spread of cells in test tubes containing semi-solid Lombard-Dowell (LD) medium after incubation for 3 days. To determine whether the novel strain exhibited aerotactic activity, bacterial cells were incubated by mixing with semi-solid LD medium at $40-50{ }^{\circ} \mathrm{C}$ in test tubes followed by incubation at $30{ }^{\circ} \mathrm{C}$ for 4 days.

Chromosomal DNA was extracted and purified according to Sambrook et al. (1989) with some modifications. A nearly complete sequence of the $16 \mathrm{~S}$ rRNA gene was obtained from a PCR product amplified from strain Be $17^{\mathrm{T}}$ by using the universal forward primer $\mathrm{P} 1$ and the universal reverse primer P6. Primer P1 (5'-AGAGTTTGATCCTGGTCAGAACGCT- $\left.3^{\prime}\right)$ corresponded to positions 8-37 and primer P6 (5'-TACGGCTACCTTGTTACGACTTCACCCC-3') corresponded to positions 1479-1506 in the Escherichia coli 16S rRNA gene (Yanagi \& Yamasato, 1993) and the fragment was sequenced as described by Ding et al. (2005). The 16S rRNA gene sequence was analysed using the EzTaxon server (Chun et al., 2007). The evolutionary distance was calculated and the phylogenetic trees were constructed using the MEGA3.1 software package (Kumar et al., 2004) with neighbour-joining and maximum-likelihood methods.

DNA-DNA hybridization and DNA G $+\mathrm{C}$ content were determined as described by Ziemke et al. (1998) and Tamaoka \& Komagata (1984), respectively.

Strains belonging to the genus Paenibacillus are often identified by PCR amplification of a 16S rRNA gene fragment with the highly specific forward primer PAEN515F (5'-GCTCGGAGAGTGACGGTACCTGAGA-3') (Shida et al., 1997) and the universal reverse primer 1377R (5'-GGCATGCTGATCCGCGATTACTAGC-3') (Shida et al., 1996). In this study, the novel isolate was further identified by this PCR amplification system.

To confirm the nitrogen-fixing capacity of strain Be $17^{\mathrm{T}}$, an assay for nitrogenase activity was performed and PCR amplification of the nifH gene was conducted. The nifH gene PCR amplification was performed as described by Ding et al. (2005). For measurement of nitrogenase activity, strain $\mathrm{Be} 17^{\mathrm{T}}$ and several reference strains were analysed by the acetylene reduction assay method (Berge et al., 2002).

Most physiological and biochemical tests, including Gram staining and determination of the optimal temperature and $\mathrm{pH}$ for growth, were performed using conventional methods. Catalase activity was analysed by bubble formation in a $3 \%(\mathrm{v} / \mathrm{v}) \mathrm{H}_{2} \mathrm{O}_{2}$ solution. Hydrolysis of casein and starch was determined as described by Cowan \& Steel (1965). The utilization of various substrates as carbon and energy sources was determined according to Shirling \& Gottlieb (1966). Resistance to antibiotics was tested as described by Gao et al. (1994). Tests for nitrate reduction, production of dextrin, the Voges-Proskauer reaction and growth inhibition by $\mathrm{NaCl}$ and lysozyme were performed according to Gordon et al. (1973), Priest et al. (1981) and Rhodes-Roberts (1981), respectively.

Analysis of cellular fatty acid content was conducted as described by Komagata \& Suzuki (1987) using the Sherlock Identification System (MIDI) (Sasser et al., 2005). Cellular menaquinones were extracted and purified as described by Collins (1985) and then analysed by HPLC. Polar lipids were extracted according to the method of Minnikin et al. (1979) and were identified by two-dimensional TLC and spraying with specific reagents as described by Collins et al. (1980). The isomer type of the diamino acid of the cell-wall peptidoglycan was determined using the methods described by Schleifer \& Kandler (1972) and Komagata \& Suzuki (1987).

Cells of strain Be $17^{\mathrm{T}}$ examined by SEM (see Supplementary Fig. S1 in IJSEM Online) showed that ellipsoidal spores were located subterminally in swollen sporangia. From the growth spread morphology and the observation that the clone grew as well on the surface as it did on the bottom of the semi-solid medium test tube, it was concluded that cells of strain Be $17^{\mathrm{T}}$ were motile and facultatively anaerobic.

The nearly complete $16 \mathrm{~S}$ rRNA gene sequence (1467 nt) of strain $B e 17^{\mathrm{T}}$ was compared by BLAST analysis with the sequences held in GenBank/EMBL/DDBJ. This analysis indicated that the novel strain was phylogenetically related to members of the genus Paenibacillus. Phylogenetic trees showing the position of the novel strain in relation to other species of the genus Paenibacillus are shown in Fig. 1 and Supplementary Fig. S2 (available with IJSEM Online). No significant differences were found between the phylogenetic trees obtained by the two different treeing methods. A more detailed phylogenetic tree that includes additional recognized species of the genus Paenibacillus is available as Supplementary Fig. S3. Strain Be17 $7^{\mathrm{T}}$ showed high levels of 16S rRNA gene sequence similarity with $P$. graminis


riograndensis CECT $7330^{\mathrm{T}}(96.2 \%)$ and P. borealis DSM $13188^{\mathrm{T}}(96.1 \%)$. Levels of $16 \mathrm{~S}$ rRNA gene sequence similarity between strain $\mathrm{Be} 17^{\mathrm{T}}$ and the type strains of 


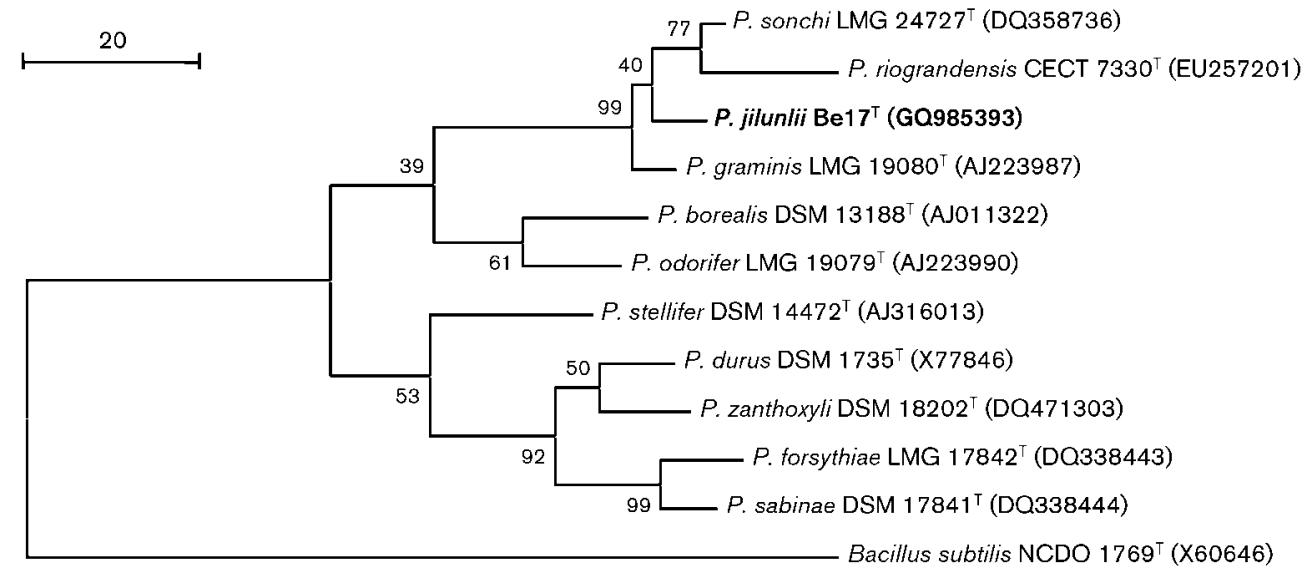

Fig. 1. Maximum-parsimony phylogenetic tree based on 16S rRNA gene sequences showing the position of strain Be17 among species of the genus Paenibacillus. Bacillus subtilis NCDO $1769^{\top}$ was used as an outgroup. Bootstrap analyses were performed with 1000 replications. Bar, 20 substitutions per nucleotide position.

other recognized members of the genus Paenibacillus were below $96.0 \%$. After amplification by PCR with PAEN515F and 1377R as the forward and reverse primers, respectively, specific segments of about $900 \mathrm{bp}$ were obtained from strain $\mathrm{Be} 17^{\mathrm{T}}$. This result further demonstrated that the novel isolate was a member of the genus Paenibacillus.

DNA-DNA hybridization tests were performed to determine the genomic relatedness between the novel strain and the type strains of $P$. graminis, $P$. sonchi and $P$. riograndensis. The DNA-DNA hybridization values between strain $\mathrm{Be}_{1} 7^{\mathrm{T}}$ and $P$. graminis $\mathrm{RSA} 19^{\mathrm{T}}, P$. sonchi LMG $24727^{\mathrm{T}}$ and $P$. riograndensis CECT $7330^{\mathrm{T}}$ were $47.9 \%, 38.7 \%$ and $37.5 \%$, respectively. According to the recommendations of the ad hoc committee, strain Be $17^{\mathrm{T}}$ and the three type strains did not belong to the same species, as the value found for DNA-DNA relatedness was lower than the threshold value of $70 \%$ (Wayne et al., 1987). The DNA G+C content of strain $B e 17^{\mathrm{T}}$ was $52.9 \mathrm{~mol} \%$ (Table 1), which was within the range of values expected for members of the genus Paenibacillus (Shida et al., 1997).

A 325 bp segment of the nifH gene was amplified by using two degenerate primers for the nitrogenase Fe protein gene. Phylogenetic trees were generated by the neighbour-joining and maximum-parsimony methods by using the MEGA3.1 software package. Phylogenetic analysis based on nifH gene sequences revealed that strain $\mathrm{Be} 17^{\mathrm{T}}$ clustered together with species of the genus Paenibacillus (Fig. 2 and Supplementary Fig. S4). The nifH gene sequence similarity between strain Be $17^{\mathrm{T}}$ and P. sonchi LMG $24727^{\mathrm{T}}$, P. borealis DSM $13188^{\mathrm{T}}$, P. forsythiae DSM $17842^{\mathrm{T}}$, P. odorifer TOD $45^{\mathrm{T}}$ and P. wynnii LMG $22176^{\mathrm{T}}$ was $95.4 \%, 82.6 \%$, $79.6 \%, 77.5 \%$ and $77.4 \%$, respectively. The results of the nitrogenase assay, as shown in Table 2 , showed that strain Be $17^{\mathrm{T}}$ exhibited significant nitrogenase activity.
Colonies of strain $\mathrm{Be} 17^{\mathrm{T}}$ on $\mathrm{LD}$ medium were circular, convex, yellow and glossy with entire margins. The phenotypic characteristics of strain $\mathrm{Be} 17^{\mathrm{T}}$ and several

Table 1. Differential phenotypic characteristics between strain $\mathrm{Be} 17^{\top}$ and the type strains of selected members of the genus Paenibacillus

Taxa: 1, strain $\mathrm{Be} 17^{\mathrm{T}} ; 2$, P. sonchi $\mathrm{LMG} 24727^{\mathrm{T}}$; 3, P. riograndensis CECT $7330^{\mathrm{T}}$; 4, P. graminis DSM $15220^{\mathrm{T}}$; 5, P. stellifer DSM $14472^{\mathrm{T}}$; 6, P. sabinae DSM $17841^{\mathrm{T}}$. + , Positive reaction; - , negative reaction.

\begin{tabular}{|lcccccc|}
\hline Characteristic & $\mathbf{1}$ & $\mathbf{2}$ & $\mathbf{3}$ & $\mathbf{4}$ & $\mathbf{5}$ & $\mathbf{6}$ \\
\hline Optimum growth temp. $\left({ }^{\circ} \mathrm{C}\right)$ & 30 & 30 & 30 & 30 & 28 & 30 \\
$3 \%(\mathrm{w} / \mathrm{v}) \mathrm{NaCl}$ & + & + & + & + & - & + \\
Growth with lysozyme & + & + & + & - & - & - \\
$(0.001 \%)$ & & & & & & \\
Voges-Proskauer & - & + & + & - & - & + \\
Nitrate reduction & + & - & - & + & - & + \\
Production of dextrin & - & + & - & - & + & - \\
Hydrolysis of: & & & & & & \\
Casein & - & + & - & - & - & - \\
Starch & + & - & + & - & + & - \\
Acid production from: & & & & & & \\
L-Aspartate & - & - & - & + & - & - \\
D-Fructose & + & + & + & - & + & - \\
D-Glucose & + & - & + & + & + & - \\
Glycerol & + & - & + & + & - & - \\
Lactose & + & - & + & + & + & - \\
Maltose & + & - & + & + & + & - \\
Sodium citrate & + & + & - & - & - & - \\
D-Sorbitol & - & - & + & - & - & - \\
Sucrose & + & - & + & - & + & - \\
D-Xylose & + & - & + & + & + & - \\
DNA G+C content $(\mathrm{mol} \%)$ & 52.9 & 46.8 & 55.1 & 52.1 & $55.6^{*}$ & 51.8 \\
& & & & & & \\
\hline
\end{tabular}

${ }^{\star}$ Data from Suominen et al. (2003). 


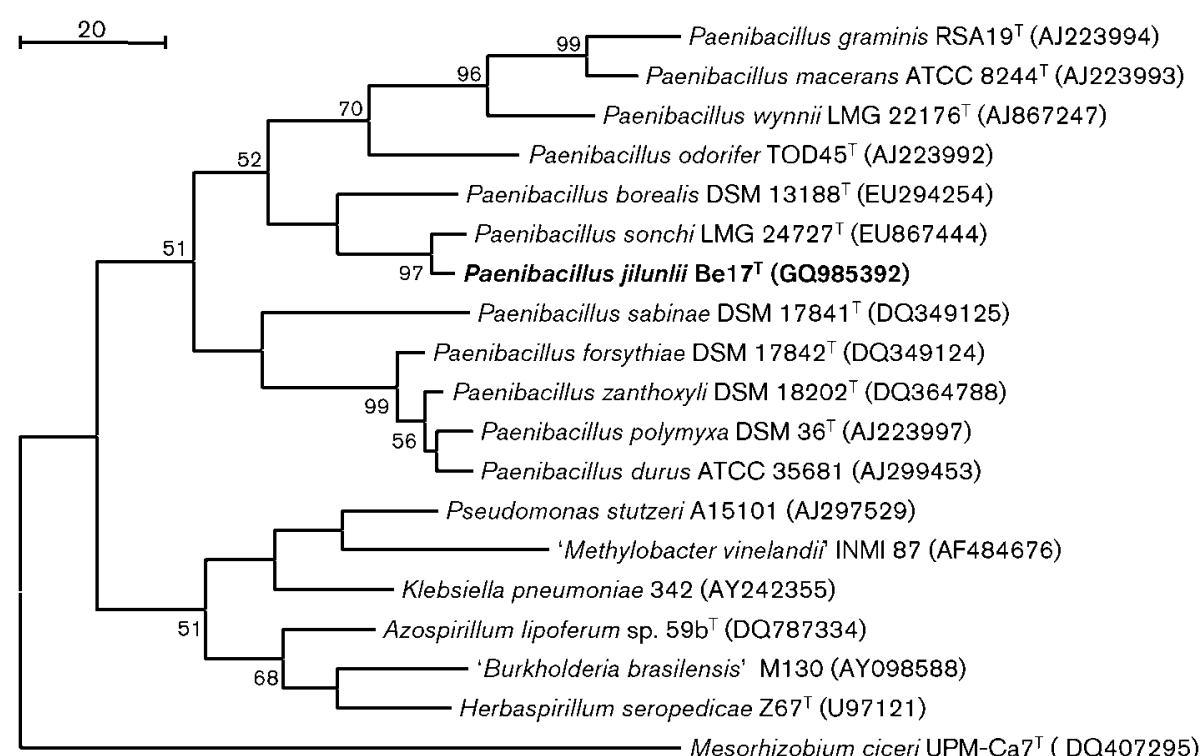

Fig. 2. Maximum-parsimony phylogenetic tree based on partial nifH gene sequence comparisons, showing the position of strain $\mathrm{Be} 17^{\top}$. Mesorhizobium ciceri was used as the outgroup. Bootstrap analyses were performed with 1000 replications. Only bootstrap values $>50 \%$ are shown at the branch points. Bar, 20 substitutions per nucleotide position.

closely related species of the genus Paenibacillus are presented in Table 1. Strain $B e 17^{\mathrm{T}}$ was found to have distinct physiological properties (Table 1) that enabled it to be distinguished from these recognized species of the genus Paenibacillus.

The major fatty acid profiles of strain $B e 17^{\mathrm{T}}$ and the type strains of closely related members of the genus Paenibacillus are shown in Table 3. The major fatty acid usually found in recognized members of the genus Paenibacillus, anteiso- $\mathrm{C}_{15: 0}$, was also the major fatty acid component of strain $\mathrm{Be}^{\mathrm{T}} \mathrm{T}^{\mathrm{T}}(30.92 \%)$. The presence of MK-7 as the major menaquinone component was in agreement with the description of the genus Paenibacillus. The major polar lipid found for strain $\mathrm{Be} 17^{\mathrm{T}}$ was

Table 2. Nitrogenase activity of strain Be $17^{\top}$ compared with some other nitrogen-fixing species of the genus Paenibacillus

Results are means \pm SD of three determinations.

\begin{tabular}{|lc|}
\hline Strain & $\begin{array}{c}\text { Nitrogenase activity [nmol } \\
\mathbf{C}_{\mathbf{2}} \mathbf{H}_{\mathbf{4}}(\mathbf{m g} \text { protein } \mathbf{~ h})^{-\mathbf{1}} \text { ] }\end{array}$ \\
\hline P. zanthoxyli DSM $18202^{\mathrm{T}}$ & $4326 \pm 127.8$ \\
P. durus ATCC 35681 & $1623 \pm 89.4$ \\
P. sabinae DSM $17841^{\mathrm{T}}$ & $287 \pm 73.5$ \\
P. forsythiae DSM $17842^{\mathrm{T}}$ & $268 \pm 55.4$ \\
P. odorifer TOD $45^{\mathrm{T}}$ & $13.4 \pm 1.33$ \\
P. polymyxa ATCC $842^{\mathrm{T}}$ & $8.74 \pm 0.84$ \\
P. graminis RSA19 & $183.5 \pm 33.7$ \\
Be17 & $236.86 \pm 36.7$ \\
\hline
\end{tabular}

diphosphatidylglycerol. Traces of phosphatidylmethylethanolamine, phosphatidylethanolamine, hydroxyphosphatidylethanolamine, phosphatidylglycerol and lysophosphatidylglycerol were also detected (see Supplementary Fig. S5 in IJSEM Online). The novel strain contained mesodiaminopimelic acid as the diagnostic diamino acid in the cell-wall peptidoglycan.

In summary, phylogenetic analysis based on the full-length 16S rRNA gene sequence, a fragment of the nifH gene sequence, DNA $\mathrm{G}+\mathrm{C}$ content and chemotaxonomic properties revealed that strain $\mathrm{Be} 17^{\mathrm{T}}$ was a member of the genus Paenibacillus. The phenotypic characteristics and low levels of DNA-DNA relatedness (below $70 \%$ ) further demonstrated that the strain $\mathrm{Be}^{\mathrm{T}} 7^{\mathrm{T}}$ represents a novel species of the genus Paenibacillus, for which the name Paenibacillus jilunlii sp. nov. is proposed.

\section{Description of Paenibacillus jilunlii sp. nov.}

Paenibacillus jilunlii (ji.lun'li.i. N.L. masc. gen. n. jilunlii of Jilun $\mathrm{Li}$, named after Professor Jilun $\mathrm{Li}$, one of the academicians of the Chinese Academy of Sciences and a pioneer of microbiology in PR China).

Cells stain Gram-positive and are facultatively anaerobic, motile, straight rod-shaped and measure 1.0-1.5 $\mu \mathrm{m} \times 2.5-$ $3.5 \mu \mathrm{m}$. Ellipsoidal spores are located subterminally in swollen sporangia. Colonies on LD medium are circular, convex, yellow and glossy with entire margins after $72 \mathrm{~h}$ incubation at $30{ }^{\circ} \mathrm{C}$ and are usually $1.5-2.5 \mathrm{~mm}$ in diameter. The temperature range for growth is $15-50{ }^{\circ} \mathrm{C}$, with optimal growth at $30{ }^{\circ} \mathrm{C}$. The $\mathrm{pH}$ range for growth is 4-9; optimal $\mathrm{pH}$ is 6.0. Grows at $3 \%(\mathrm{w} / \mathrm{v}) \mathrm{NaCl}$, but is 
Table 3. Cellular fatty acid profiles of strain $\mathrm{Be} 17^{\top}$ and closely related type strains of the genus Paenibacillus

Taxa: 1, strain Be17 ${ }^{\mathrm{T}}$; 2, P. sonchi LMG $24727^{\mathrm{T}} ; 3$, P. riograndensis CECT $7330^{\mathrm{T}}$; 4, P. graminis DSM 15220 ${ }^{\mathrm{T}} ; 5$, P. durus DSM $1735^{\mathrm{T}}$; 6 , P. zanthoxyli DSM $18202^{\mathrm{T}} ; 7$, P. forsythiae DSM $17842^{\mathrm{T}} ; 8$, P. sabinae DSM $17841^{\mathrm{T}}$. Values are percentages of the total fatty acids. For unsaturated fatty acids, the position of the double bond can be located by counting from the methyl $(\omega)$ end of the carbon chain; cis isomers are indicated by the suffix $c$. The results shown were determined under the same conditions for all strains. ND, not detected.

\begin{tabular}{|c|c|c|c|c|c|c|c|c|}
\hline Fatty acid & 1 & 2 & 3 & 4 & 5 & 6 & 7 & 8 \\
\hline \multicolumn{9}{|c|}{ Saturated straight-chain } \\
\hline $\mathrm{C}_{14: 0}$ & 5.22 & 3.61 & 6.96 & 7.35 & 4.76 & 4.84 & 4.79 & 2.93 \\
\hline $\mathrm{C}_{16: 0}$ & 11.78 & 8.58 & 16.78 & 7.06 & 19.87 & 12.88 & 18.59 & 18.07 \\
\hline $\mathrm{C}_{18: 0}$ & ND & 0.91 & 0.49 & 2.43 & 5.48 & 6.77 & 5.73 & 3.24 \\
\hline \multicolumn{9}{|c|}{ Saturated iso-branched } \\
\hline iso- $\mathrm{C}_{14: 0}$ & 15.03 & 22.12 & 4.97 & 28.48 & 5.31 & 3.79 & 2.66 & 3.24 \\
\hline iso- $\mathrm{C}_{15: 0}$ & 4.30 & 4.71 & 6.29 & 4.97 & 7.89 & 1.63 & 0.99 & 1.40 \\
\hline iso- $\mathrm{C}_{16: 0}$ & 13.32 & 16.10 & 6.53 & 11.18 & 10.58 & 14.90 & 11.53 & 14.44 \\
\hline iso- $\mathrm{C}_{17: 0}$ & ND & 0.64 & 0.89 & ND & 1.48 & 0.59 & 0.95 & 0.82 \\
\hline \multicolumn{9}{|c|}{ Saturated anteiso-branched } \\
\hline anteiso- $\mathrm{C}_{15: 0}$ & 30.92 & 35.95 & 44.45 & 36.23 & 39.76 & 32.25 & 29.97 & 36.62 \\
\hline anteiso- $\mathrm{C}_{17: 0}$ & 1.88 & 1.07 & 1.79 & 0.37 & 1.94 & 3.87 & 4.61 & 6.34 \\
\hline \multicolumn{9}{|l|}{ Unsaturated } \\
\hline $\mathrm{C}_{18: 1} \omega 9 c$ & ND & 0.37 & 0.85 & 0.61 & 2.12 & 1.54 & 4.83 & 3.85 \\
\hline
\end{tabular}

unable to tolerate $5 \%(\mathrm{w} / \mathrm{v}) \mathrm{NaCl}$. Growth is not inhibited by $0.001 \%(\mathrm{w} / \mathrm{v})$ lysozyme. Catalase- and oxidase-negative. Negative for the Voges-Proskauer reaction. Nitrate is reduced to nitrite. Nitrogen is fixed. The following substrates are utilized for growth and acid production: cellobiose, D-fructose, D-galactose, D-glucose, D-mannose, raffinose, trehalose, D-xylose, inositol, inulin, glycerol, lactose, L-arabinose, maltose, mannitol, $N$-acetyl-D-glucosamine, sodium citrate and sucrose. Acids are not produced from creatine, D-sorbitol, DL-malic acid, L-sorbose, Laspartate, sodium DL-malate or sodium succinate. Gelatin is not hydrolysed. Starch is hydrolysed, but casein is not. The predominant menaquinone is MK-7. The cell wall contains meso-diaminopimelic acid as the diagnostic diamino acid. The major fatty acids are anteiso- $\mathrm{C}_{15: 0}$ and iso- $\mathrm{C}_{14: 0}$. The type strain is sensitive to $\left(\mu \mathrm{g} \mathrm{ml}^{-1}\right)$ : ampicillin (100), gentamicin (40) and chloromycetin (30), but resistant to kanamycin (50), spectinomycin (100), streptomycin (40) and tetracycline (12.5).

The type strain, Be $17^{\mathrm{T}}$ (=CGMCC $1.10239^{\mathrm{T}}=\mathrm{DSM}$ $23019^{\mathrm{T}}$ ), was isolated from the rhizosphere soil of Begonia semperflorens grown in Beijing, P. R. China. The DNA G $+C$ content of the type strain is $52.9 \mathrm{~mol} \%$ (thermal denaturation method).

\section{Acknowledgements}

We thank Dr Odile Berge in France and Professor Mirja SalkinojaSalonen at Helsinki University for their generous gifts of the reference type strains. We are grateful to Dr R. Pukall for his generous help when the strain was deposited in the DSMZ. We also thank Professor Jose E. Ruiz-Sainz at the University of Seville, Spain, who provided help in posting reference strains from Spain. This work was supported by funds from the National '973' Project (grant no. 2010CB126504).

\section{References}

Ash, C., Farrow, J. A. E., Wallbanks, S. \& Collins, M. D. (1991). Phylogenetic heterogeneity of the genus Bacillus revealed by comparative analysis of small-subunit-ribosomal RNA sequences. Lett Appl Microbiol 13, 202-206.

Ash, C., Priest, F. G. \& Collins, M. D. (1993). Molecular identification of rRNA group 3 bacilli (Ash, Farrow, Wallbanks and Collins) using a PCR probe test. Proposal for the creation of a new genus Paenibacillus. Antonie van Leeuwenhoek 64, 253-260.

Ash, C., Priest, F. G. \& Collins, M. D. (1994). Paenibacillus gen. nov. In Validation of the Publication of New Names and New Combinations Previously Effectively Published Outside the IJSB, List no. 51. Int J Syst Bacteriol 44, 852.

Beneduzi, A., Costa, P. B., Parma, M., Melo, I. S., BodaneseZanettini, M. H. \& Passaglia, L. M. (2010). Paenibacillus riograndensis sp. nov., a nitrogen-fixing species isolated from the rhizosphere of Triticum aestivum. Int J Syst Evol Microbiol 60, 128-133.

Berge, O., Guinebretière, M. H., Achouak, W., Normand, P. \& Heulin, T. (2002). Paenibacillus graminis sp. nov. and Paenibacillus odorifer sp. nov., isolated from plant roots, soil and food. Int J Syst Evol Microbiol 52, 607-616.

Chun, J., Lee, J. H., Jung, Y., Kim, M., Kim, S., Kim, B. K. \& Lim, Y. W. (2007). EzTaxon: a web-based tool for the identification of prokaryotes based on $16 \mathrm{~S}$ ribosomal RNA gene sequences. Int J Syst Evol Microbiol 57, 2259-2261.

Coelho, M. R. R., Carneiro, N. P., Marriel, I. E. \& Seldin, L. (2009). Molecular detection of nifH gene-containing Paenibacillus in the rhizosphere of sorghum (Sorghum bicolor) sown in Cerrado soil. Lett Appl Microbiol 48, 611-617.

Collins, M. D. (1985). Analysis of isoprenoid quinones. Methods Microbiol 18, 329-366.

Collins, M. D., Goodfellow, M. \& Minnikin, D. E. (1980). Fatty acid, isoprenoid quinone and polar lipid composition in the classification of Curtobacterium and related taxa. J Gen Microbiol 118, 29-37.

Cowan, S. T. \& Steel, K. J. (1965). Manual for the Identification of Medical Bacteria. London: Cambridge University Press. 
Ding, Y., Wang, J., Liu, Y. \& Chen, S. (2005). Isolation and identification of nitrogen-fixing bacilli from plant rhizospheres in Beijing region. J Appl Microbiol 99, 1271-1281.

Elo, S., Suominen, I., Kämpfer, P., Juhanoja, J., Salkinoja-Salonen, M. \& Haahtela, K. (2001). Paenibacillus borealis sp. nov., a nitrogen-fixing species isolated from spruce forest humus in Finland. Int J Syst Evol Microbiol 51, 535-545.

Gao, J. L., Sun, J. G., Li, Y., Wang, E. T. \& Chen, W. X. (1994). Numerical taxonomy and DNA relatedness of tropical rhizobia isolated from Hainan Province, China. Int J Syst Bacteriol 44, 151-158.

Gordon, R. E., Haynes, W. C. \& Pang, C. H.-N. (1973). The Genus Bacillus (US Department of Agriculture Handbook no. 427). Washington, DC: Agricultural Research Service.

Hong, Y. Y., Ma, Y. C., Zhou, Y. G., Gao, F., Liu, H. C. \& Chen, S. F. (2009). Paenibacillus sonchi sp. nov., a nitrogen-fixing species isolated from the rhizosphere of Sonchus oleraceus. Int J Syst Evol Microbiol 59, 2656-2661.

Komagata, K. \& Suzuki, K. (1987). Lipid and cell-wall analysis in bacterial systematics. Methods Microbiol 19, 161-207.

Kumar, S., Tamura, K. \& Nei, M. (2004). MEGA3: Integrated software for molecular evolutionary genetics analysis and sequence alignment. Brief Bioinform 5, 150-163.

Ma, Y. C. \& Chen, S. F. (2008). Paenibacillus forsythiae sp. nov., a nitrogen-fixing species isolated from rhizosphere soil of Forsythia mira. Int J Syst Evol Microbiol 58, 319-323.

Ma, Y., Xia, Z., Liu, X. \& Chen, S. (2007). Paenibacillus sabinae sp. nov., a nitrogen-fixing species isolated from the rhizosphere soils of shrubs. Int J Syst Evol Microbiol 57, 6-11.

Minnikin, D. E., Collins, M. D. \& Goodfellow, M. (1979). Fatty acid and polar lipid composition in the classification of Cellulomonas, Oerskovia and related taxa. J Appl Bacteriol 47, 87-95.

Priest, F. G., Goodfellow, M. \& Todd, C. (1981). The genus Bacillus: a numerical analysis. In The Aerobic Endospore-Forming Bacteria: Classification and Identification, pp. 91-103. Edited by R. C. W. Berkeley \& M. Goodfellow. London: Academic Press.

Rhodes-Roberts, M. (1981). The taxonomy of some nitrogen-fixing Bacillus species with special reference to nitrogen fixation. In The Aerobic Endospore-Forming Bacteria: Classification and Identification, pp. 315-335. Edited by R. C. W. Berkeley \& M. Goodfellow. London: Academic Press.

Saha, P., Mondal, A. K., Mayilraj, S., Krishnamurthi, S., Bhattacharya, A. \& Chakrabarti, T. (2005). Paenibacillus assamensis sp. nov., a novel bacterium isolated from a warm spring in Assam, India. Int J Syst Evol Microbiol 55, 2577-2581.
Sambrook, J., Fritsch, E. F. \& Maniatis, T. (1989). Molecular Cloning: a Laboratory Manual, 2nd edn. Cold Spring Harbor, NY: Cold Spring Harbor Laboratory.

Sasser, M., Kunitsky, C., Jackoway, G., Ezzell, J. W., Teska, J. D., Harper, B., Parker, S., Barden, D., Blair, H. \& other authors (2005). Identification of Bacillus anthracis from culture using gas chromatographic analysis of fatty acid methyl esters. J AOAC Int 88, 178181.

Schleifer, K. H. \& Kandler, O. (1972). Peptidoglycan types of bacterial cell walls and their taxonomic implications. Bacteriol Rev 36, 407477.

Shida, O., Takagi, H., Kadowaki, K. \& Komagata, K. (1996). Proposal for two new genera, Brevibacillus gen. nov. and Aneurinibacillus gen. nov. Int J Syst Bacteriol 46, 939-946.

Shida, O., Takagi, H., Kadowaki, K., Nakamura, L. K. \& Komagata, K. (1997). Transfer of Bacillus alginolyticus, Bacillus chondroitinus, Bacillus curdlanolyticus, Bacillus glucanolyticus, Bacillus kobensis, and Bacillus thiaminolyticus to the genus Paenibacillus and emended description of the genus Paenibacillus. Int J Syst Bacteriol 47, 289298.

Shirling, E. B. \& Gottlieb, D. (1966). Methods for characterization of Streptomyces species. Int J Syst Bacteriol 16, 313-340.

Suominen, I., Spröer, C., Kämpfer, P., Rainey, F. A., Lounatmaa, K. \& Salkinoja-Salonen, M. (2003). Paenibacillus stellifer sp. nov., a cyclodextrin-producing species isolated from paperboard. Int J Syst Evol Microbiol 53, 1369-1374.

Tamaoka, J. \& Komagata, K. (1984). Determination of DNA base composition by reversed-phase high-performance liquid chromatography. FEMS Microbiol Lett 25, 125-128.

Von Bredemann, G. (1908). Untersuchungen uber die Variation und das Stickstoffbindungsvermogen des Bacillus asterosporus A. M., ausgefuhrt an 27 Stammen verschiedener Herkunft. Zentralblatt Bakteriol Parasitenkd Infekt Hyg 2, 44-89.

Wayne, L. G., Brenner, D. J., Colwell, R. R., Grimont, P. A. D., Kandler, O., Krichevsky, M. I., Moore, L. H., Moore, W. E. C., Murray, R. G. E. \& other authors (1987). International Committee on Systematic Bacteriology. Report of the ad hoc committee on reconciliation of approaches to bacterial systematics. Int J Syst Bacteriol 37, 463-464.

Yanagi, M. \& Yamasato, K. (1993). Phylogenetic analysis of the family Rhizobiaceae and related bacteria by sequencing of $16 \mathrm{~S}$ rRNA gene using PCR and DNA sequencer. FEMS Microbiol Lett 107, 115-120.

Ziemke, F., Höfle, M. G., Lalucat, J. \& Rosselló-Mora, R. (1998). Reclassification of Shewanella putrefaciens Owen's genomic group II as Shewanella baltica sp. nov. Int J Syst Bacteriol 48, 179-186. 